\title{
Application of weights-of-evidence and certainty factor models and their comparison in landslide susceptibility mapping at Haraz watershed, Iran
}

\author{
Hamid Reza Pourghasemi • Biswajeet Pradhan • \\ Candan Gokceoglu • Majid Mohammadi • \\ Hamid Reza Moradi
}

Received: 4 September 2011 / Accepted: 8 February 2012 / Published online: 9 March 2012

(C) Saudi Society for Geosciences 2012

\begin{abstract}
The main goal of this study was to investigate the application of the weights-of-evidence and certainty factor approaches for producing landslide susceptibility maps of a landslide-prone area (Haraz) in Iran. For this purpose, the input layers of the landslide conditioning factors were prepared in the first stage. The landslide conditioning factors considered for the study area were slope gradient, slope aspect, altitude, lithology, land use, distance from streams, distance from roads, distance from faults, topographic wetness index, stream power index, stream transport index and plan curvature. For validation of the produced landslide susceptibility maps, the results of the analyses were compared with the field-verified landslide locations. Additionally, the receiver operating characteristic curves for all the landslide susceptibility models were constructed and
\end{abstract}

H. R. Pourghasemi $\cdot$ M. Mohammadi $\cdot$ H. R. Moradi Department of Watershed Management Engineering, College of Natural Resources and Marine Sciences, Tarbiat Modares University International Campus,

Noor, Iran

e-mail: hm_porghasemi@yahoo.com

B. Pradhan $(\bowtie)$

Institute of Advanced Technology, Spatial and Numerical

Modelling Laboratory, University Putra Malaysia,

43400 UPM Serdang, Selangor Darul Ehsan, Malaysia

e-mail: biswajeet24@gmail.com

B. Pradhan

e-mail: biswajeet@mailcity.com

C. Gokceoglu

Applied Geology Division, Department of Geological

Engineering, Engineering Faculty, Hacettepe University,

Ankara, Turkey the areas under the curves were calculated. The landslide locations were used to validate results of the landslide susceptibility maps. The verification results showed that the weights-of-evidence model (79.87\%) performed better than certainty factor $(72.02 \%)$ model with a standard error of 0.0663 and 0.0756 , respectively. According to the results of the area under curve evaluation, the map produced by weights-of-evidence exhibits satisfactory properties.

Keywords Landslide susceptibility . Weights of evidence . Certainty factor model · GIS · Remote sensing · Iran

\section{Introduction}

Landslides are one of the most catastrophic natural hazards occurring in many areas of the world. Globally, they cause hundreds of billions of dollars in damage and hundreds of thousands of deaths and injuries each year (Aleotti and Chowdhury 1999). Over the past 25 years, many governments and research institutions throughout the world have invested considerable resources in assessing landslide hazards and in attempting to produce maps portraying their spatial distribution (Guzzetti et al. 1999). In spite of improvements in recognition, mitigative measures, and prediction and warning systems, landslide damage is still increasing worldwide (Schuster 1996). Losses resulting from mass movements in Iran until the end of September 2007 have been estimated at 126,893 billion Iranian Rials (about USD 12,700 million) using the 4,900 landslide database.

Similar approaches have been proposed by several investigators, including weights-of-evidence methods 
(Bonham-Carter 1991; Lee et al. 2002a; Wu et al. 2004; Gokceoglu et al. 2005; Neuhäuser and Terhorst 2007; Mathew et al. 2007; Bui et al. 2008; Zhu and Wang 2009; Regmi et al. 2010; Oh and Lee 2011), weighting factors (Çevik and Topal 2003), weighted linear combinations of instability factors (Ayalew et al. 2004), landside nominal risk factors (Gupta and Joshi 1990; Saha et al. 2005), probabilistic models (Chung and Fabbri 2003, 2005; Lee 2004; Lee and Pradhan 2006, 2007; Akgun et al. 2011; Pradhan et al. 2012), certainty factors (Binaghi et al. 1998), information values (Lin and Tung 2004; Saha et al. 2005), modified Bayesian estimation (Chung and Fabbri 1998) and data mining (Biswajeet and Saied 2010; Pradhan et al. 2009, 2010a, b, c, d, e, 2011 Pradhan 2010a, b, c, 2011a, b Pradhan and Lee 2010a, b; Pradhan and Buchroithner 2010; Pradhan and Youssef 2010; Sezer et al. 2011; Oh and Pradhan 2011; Bui et al. 2011; Akgun et al. 2012). Understanding the differences between the proposed approaches is not always simple. The main differences are the rigour of the approach (Chung and Fabbri 1998) and the method used to estimate the prior probability of landslide occurrence. The aim of the present study was to produce landslide susceptibility maps of the Haraz watershed in Iran by employing a weights-of-evidence and certainty factor models.

\section{Study area}

The study area is located in the northern part of Iran, which is one of the most landslide-prone areas in the country (Pourghasemi 2008). The watershed area lies between longitudes $52^{\circ} 06^{\prime} 02^{\prime \prime} \mathrm{E}$ and $52^{\circ} 18^{\prime} 13^{\prime \prime} \mathrm{E}$ and between latitudes $35^{\circ} 49^{\prime} 05^{\prime \prime} \mathrm{N}$ and $35^{\circ} 57^{\prime} 39^{\prime \prime} \mathrm{N}$. It is mountainous and is located in the Alborz Folded geological zone (Fig. 1). It covers two adjacent 1:50,000 topographic sheets of the Army Geographic Institute of Iran and has an extent of

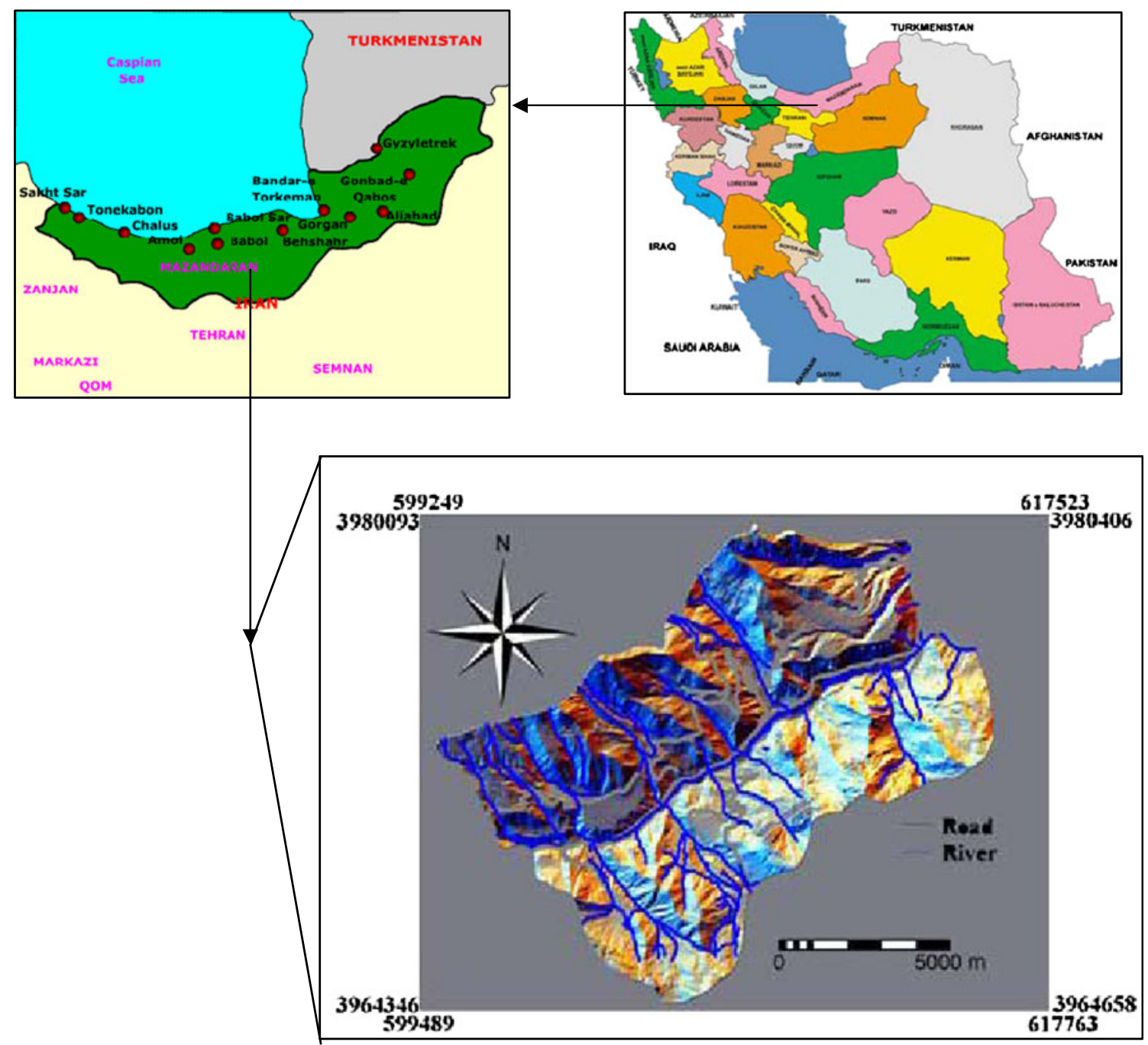

Fig. 1 Location map of the study area in Mazandaran province, Iran 
about $114.5 \mathrm{~km}^{2}$. The main river in the study area is the Haraz River. The temperature varies between $25^{\circ} \mathrm{C}$ in winter and $36.5^{\circ} \mathrm{C}$ in summer. The mean annual rainfall is around $500 \mathrm{~mm}$, most of which falls between November and January. The altitudes in the study area vary between 1,200 and $3,290 \mathrm{~m}$. The slope angles of the area range from $0^{\circ}$ to as much as $70^{\circ}$. The majority of the area $(64.82 \%)$ is covered by moderate pasture. The other parts of the study area are utilised for orchard and agricultural $(13.33 \%)$, residential $(0.3 \%)$ and best pasture purposes (21.55\%).

\section{Weights-of-evidence model}

In recent years, many investigators (Bonham-Carter 1991; Mathew et al. 2007; Neuhäuser and Terhorst 2007; Bui et al. 2008; Regmi et al. 2010; Pradhan et al. 2010c) have experimented with methods that exploit, more or less rigorously, Bayes' conditional probability theorem. In this framework, conditional probability is a measure of the chance of a hypothesis being true or false given a piece of evidence (Gorsevski et al. 2003). For example, Bayesian probabilistic modelling is supplied for solving problems of decision-making under uncertainties. This method is suitable for landslide susceptibility mapping because its uncertainty is connected with landslide events and their associations with the complex landscape (Chung and Fabbri 1998; Gorsevski et al. 2003). Bayes' theorem can be written as (Guzzetti 2005):
$P(A \mid B)=\frac{P(B \mid A) \times P(A)}{P(B)}$

So, the probability of phenomena $B$ occurring given that phenomena A has occurred, $\mathrm{P}(B \mid A)$, multiplied by the probability of phenomena A occurring, $P(A)$, and divided by the probability of phenomena $\mathrm{B}$ occurring, $P(B)$.

In Eq. 1, $P(A)$ is the "prior probability" (i.e. a reasonable hypothesis on the probability of phenomena $\mathrm{A}), P(B)$ is the "posterior probability" (i.e. the probability of $\mathrm{B}$ under all possible outcomes for $\mathrm{A}$ ), and $\mathrm{P}(A \mid B)$ is the "probability" (i.e. the conditional probability of A given B). In a best Bayesian analysis, the prior probability has a minor effect on the posterior probability, as most of the information comes from the likelihood. When applied to landslide susceptibility investigation, Bayes' theorem is used to select the probability that an area will improve slope failures given the local environmental circumstances, as indicated in Eq. 2 (Chung and Fabbri 1998):

$$
\begin{aligned}
P & \left(A_{L} \mid\left\{V_{0}(r), V_{1}(r) \ldots, V_{m}(r)\right\}\right) \\
& =\frac{P\left(\left\{V_{0}(r), V_{1}(r) \ldots, V_{m}(r)\right\} \mid A_{L}\right) \times P\left(A_{L}\right)}{P\left(V_{0}(r), V_{1}(r), \ldots, V_{m}(r)\right)}
\end{aligned}
$$

where, $A_{L}$ denotes area of landslide in a mapping unit $r$ for which $\left\{V_{0}(r), V_{1}(r) \ldots, V_{m}(r)\right\}$ is independent of environmental conditions. Additionally, the mixture of environmental conditions is special to the mapping unit $r$. Equation 2 showed that the probability that a mapping
Fig. 2 The landslide inventory map of the study area

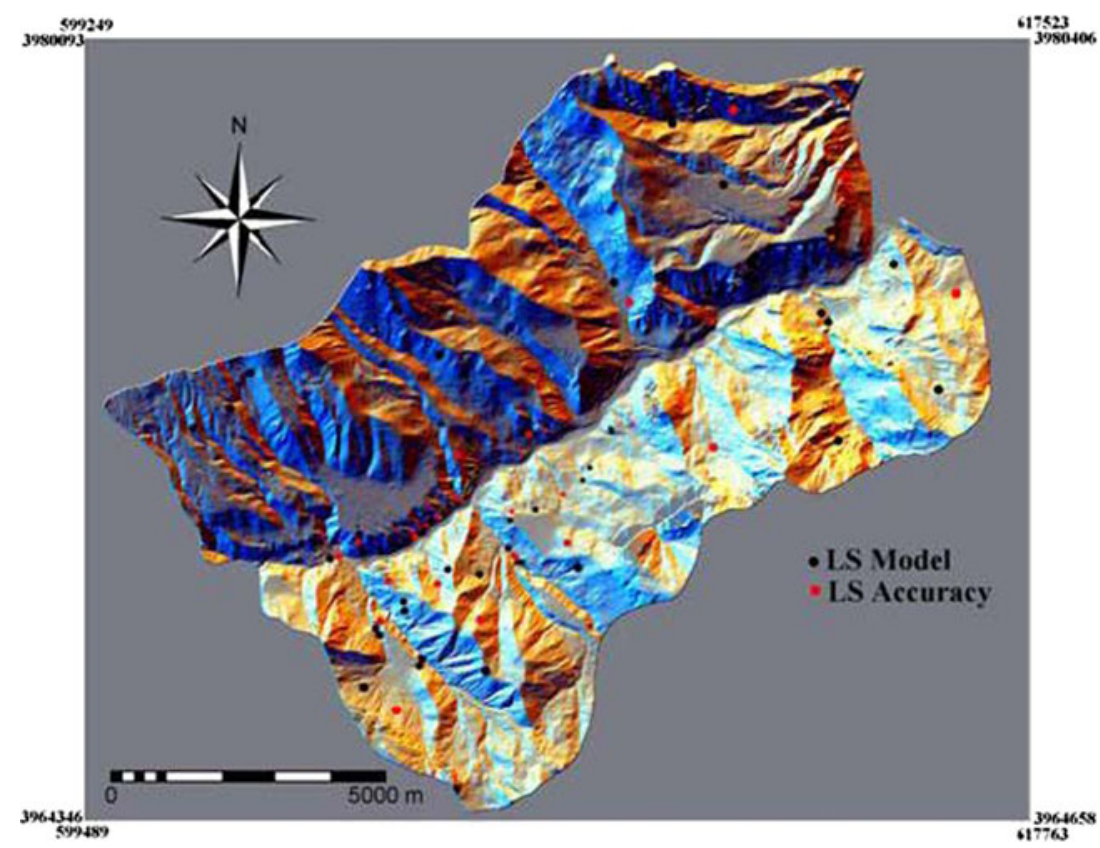


Fig. 3 Lithology map of the study area

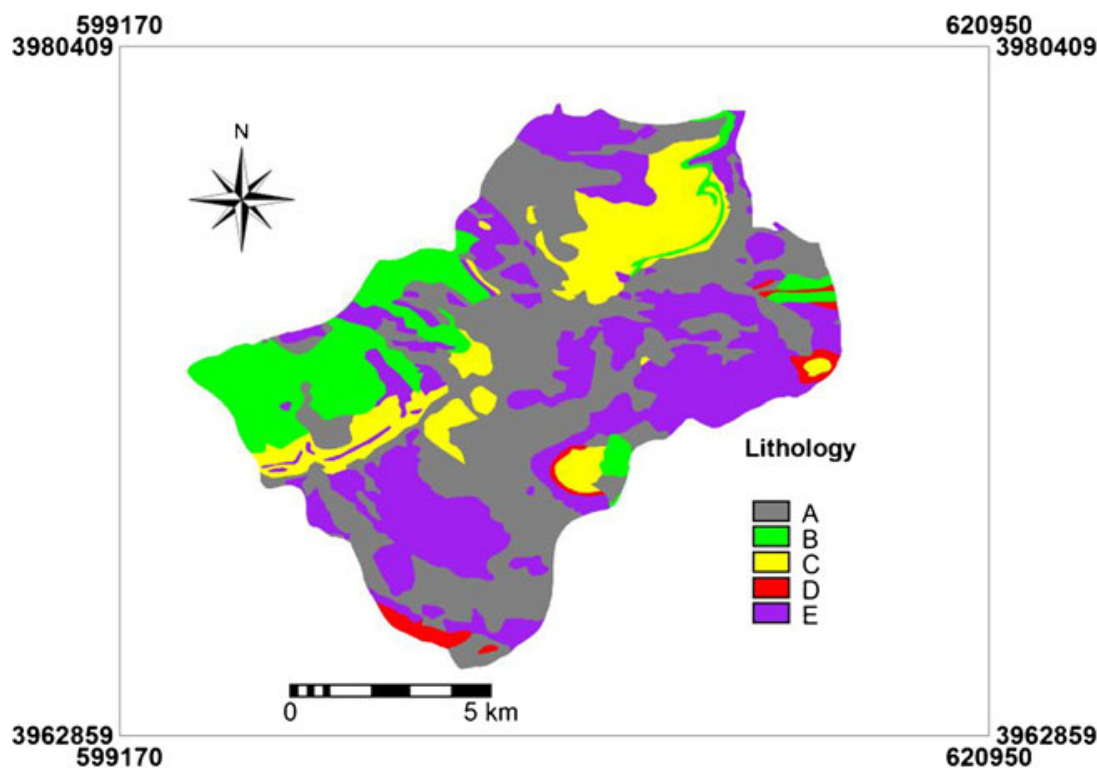

unit $r$ in the study area will be influenced by a landslide which is equivalent to the probability of a landslide in the study area, $P\left(A_{L}\right)$, multiplied by the probability of a particular (unique) mixture of environmental factors given the presence of a landslide, divided by the probability of the same mixture of environmental factors in the whole study area. A simple strategy is to acquire the three probabilities in the right- hand side of Eq. 2 in a geographic information system (GIS) from the related spatial densities. These probabilities can be obtained as follows: (1) by dividing the entire $A_{L}$ in the study area by the area of the mapping unit, for $P\left(A_{L}\right)$; (2) by dividing the whole area of the unique condition unit by the extent of the study area for $P\left(V_{0}(r), V_{1}(r), \ldots, V_{m}(r)\right)$; and (3) by considering the percentage of the landslide area in the study area
Table 1 Description of geological units of the study area

\begin{tabular}{|c|c|c|c|c|}
\hline No. & Symbol & Formation & Lithology & Geological age \\
\hline \multirow[t]{3}{*}{ A } & $Q^{\mathrm{sc}}$ & - & Scree & Quaternary \\
\hline & $Q_{2}^{t}$ & - & Young terraces & Quaternary \\
\hline & $Q_{1}^{t}$ & - & Old terraces & Quaternary \\
\hline \multirow[t]{4}{*}{$\mathrm{B}$} & $Q^{\mathrm{ag}}$ & - & Agglomerate & Quaternary \\
\hline & $Q^{\mathrm{ta}}$ & - & Trachy andesitic lava flows & Quaternary \\
\hline & $Q^{\text {tu }}$ & - & Ash tuff, lapilli tuff & Quaternary \\
\hline & $Q^{\mathrm{b}}$ & - & Olivine basalt & Quaternary \\
\hline \multirow[t]{2}{*}{$\mathrm{C}$} & $K_{k}^{\mathrm{tv}}$ & Karaj & $\begin{array}{l}\text { Green tuff, basaltic and limestone with gypsum and } \\
\text { conglomerate }\end{array}$ & Eocene \\
\hline & $E_{k}^{\mathrm{gy}}$ & Karaj & Gypsum & Eocene \\
\hline \multirow[t]{2}{*}{$\mathrm{D}$} & $\mathrm{PE} z$ & Ziarat & Limestone bearing nummulites and alveolina, conglomerate & Paleocene \\
\hline & $\mathrm{PE} f$ & Fajan & Conglomerate, agglomerate, some marl and limestone & Paleocene \\
\hline \multirow[t]{7}{*}{$\mathrm{E}$} & $K 2$ & - & Biogenic and cherty limestone & $\begin{array}{l}\text { Late } \\
\text { Cretaceous }\end{array}$ \\
\hline & Kt & Tizkuh & Orbitoline bearing limestone & $\begin{array}{l}\text { Late } \\
\text { Cretaceous }\end{array}$ \\
\hline & $J 1$ & Lar & Massive to well bedded, cherty limestone & Late Jurassic \\
\hline & $J d$ & Dalichai & Well bedded, partly oolitic-detritic limestone, marly limestone & Late Jurassic \\
\hline & JS & Shemshak & Dark shale and sandstone with plant remains, coal & Late Jurassic \\
\hline & TReL & Elika & Thin bedded limestone & Early Triassic \\
\hline & Pd & Dorud & Cross-bedded, quartzitic sandstone & Early Permian \\
\hline
\end{tabular}




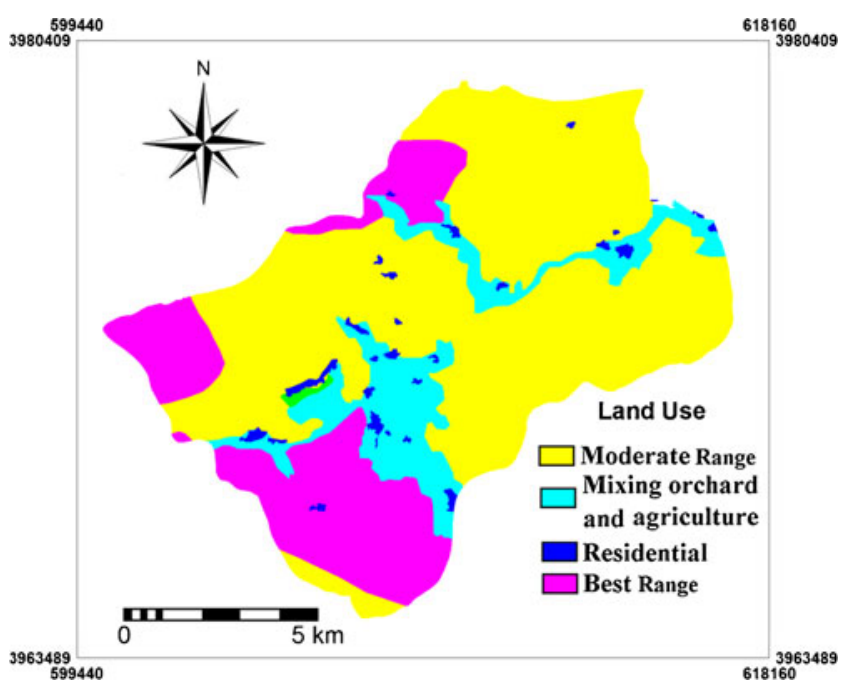

Fig. 4 Land use map of the study area

characterised by the total area of the unique environmental setting in Eq. 2, for $P\left(\left\{V_{0}(r), V_{1}(r) \ldots, V_{m}(r)\right\} \mid A_{L}\right)$.

An advantage of Bayesian probabilistic modelling is the possibility of incorporating uncertainty into the susceptibility model and considering expert knowledge explicitly (Chung and Fabbri 1998).

\section{Certainty factor model}

Among the commonly used GIS analysis models for landslide susceptibility, certainty factor (CF) model has been widely considered and experimentally investigated in the literature (Chung and Fabbri 1993; Binaghi et al. 1998; Luzi and Pergalani 1999; Lan et al. 2004; Kanungo et al. 2011). The CF approach is one of the possible proposed favourability functions to handle the problem of combination of different data layers and the heterogeneity and uncertainty of the input data. The main difference is the bivariate model with other models of how to combine the maps. Thus, the maps classifieds and then weight of each pixel is obtained using Eq. 3:

$\mathrm{CF}=\left\{\begin{array}{lll}\frac{\mathrm{PP}_{a}-\mathrm{PP}_{s}}{\mathrm{PP}_{a}\left(1-\mathrm{PP}_{s}\right)} & \text { if } & \mathrm{PP}_{a} \geq \mathrm{PP}_{s} \\ \frac{\mathrm{PP}_{a}-\mathrm{PP}_{s}}{\mathrm{PP}_{s}\left(1-\mathrm{PP}_{a}\right)} & \text { if } & \mathrm{PP}_{a}<\mathrm{PP}_{s}\end{array}\right.$

where, $\mathrm{PP}_{a}$ is the conditional probability of landslide event occurring in class a and $\mathrm{PP}_{s}$ is the prior probability of total number of landslide events in the study area A. With the use of the CF model, each class or area is assigned a value that varies within the interval $[-1,1]$. A positive value means a growth in the certainty of the landslide occurrence, whereas a negative value coincides with a decrease in the certainty of landslide occurrence. A value close to 0 means that there is not enough information about the variable and thus, it is difficult to give information about the certainty of landslide occurrence. The $\mathrm{CF}$ values are calculated for all condition factors by overlaying and calculating the landslide frequency as given then the $\mathrm{CF}$ values of all parameters in 12 landslide conditioning factors are determined using Eq. 3. Next, the $\mathrm{CF}$ values of the landslide conditioning factor are pairwise combined using the $\mathrm{CF}$ combination rule. A combination of two $C F$ values, $X$ and $Y$ from two different layers of information is a CF value $Z$ obtained as follows (Chung and Fabbri 1993; Binaghi et al. 1998; Luzi and Pergalani 1999):

$Z= \begin{cases}X+Y-X Y & X, Y \geq 0 \\ \frac{X+Y}{1-\min (|X|,|Y|)} & X, Y \text { opposite sign } \\ X+Y+X Y & X, Y<0\end{cases}$

The pairwise combination by using the integration rule of Eq. 4 is performed repeatedly until all the CF layers are combined to obtain the landslide susceptibility.

\section{Thematic data preparation}

Various thematic data layers representing landslide conditioning factors, such as slope gradient, slope aspect, altitude, lithology, land use, distance to faults, distance to streams, distance to roads, topographic wetness index (TWI), stream power index (SPI), stream transport index (STI) and plan curvature were prepared. These factors fall under the category of preparatory factors, which make the area susceptible to movement without actually initiating a landslide; thus, these factors are considered to be responsible for the occurrence of landslides in the regions for which pertinent data can be collected from available resources and from the field. The triggering factors, such as rainfall and earthquake, set the movement off by shifting the slope from a marginally stable to an actively unstable area. Furthermore, the attributes of the ground in terms of landslide susceptibility were considered in the present study. Since, past data on triggering factors such as rainfall and earthquakes in relation to landslide occurrences were not available. Consequently, these factors were not considered in this study.

Landslide inventory map

The mapping of existing landslides is essential for studying the relationship between the landslide distribution and the conditioning factors. To produce a detailed and reliable landslide inventory map, extensive field surveys and observations were performed in the study area. A total of 78 landslides were identified and mapped in the study area by evaluating aerial photos in 1:25,000 scale and by field survey (Fig. 2). The modes of failure for the landslides identified in the 

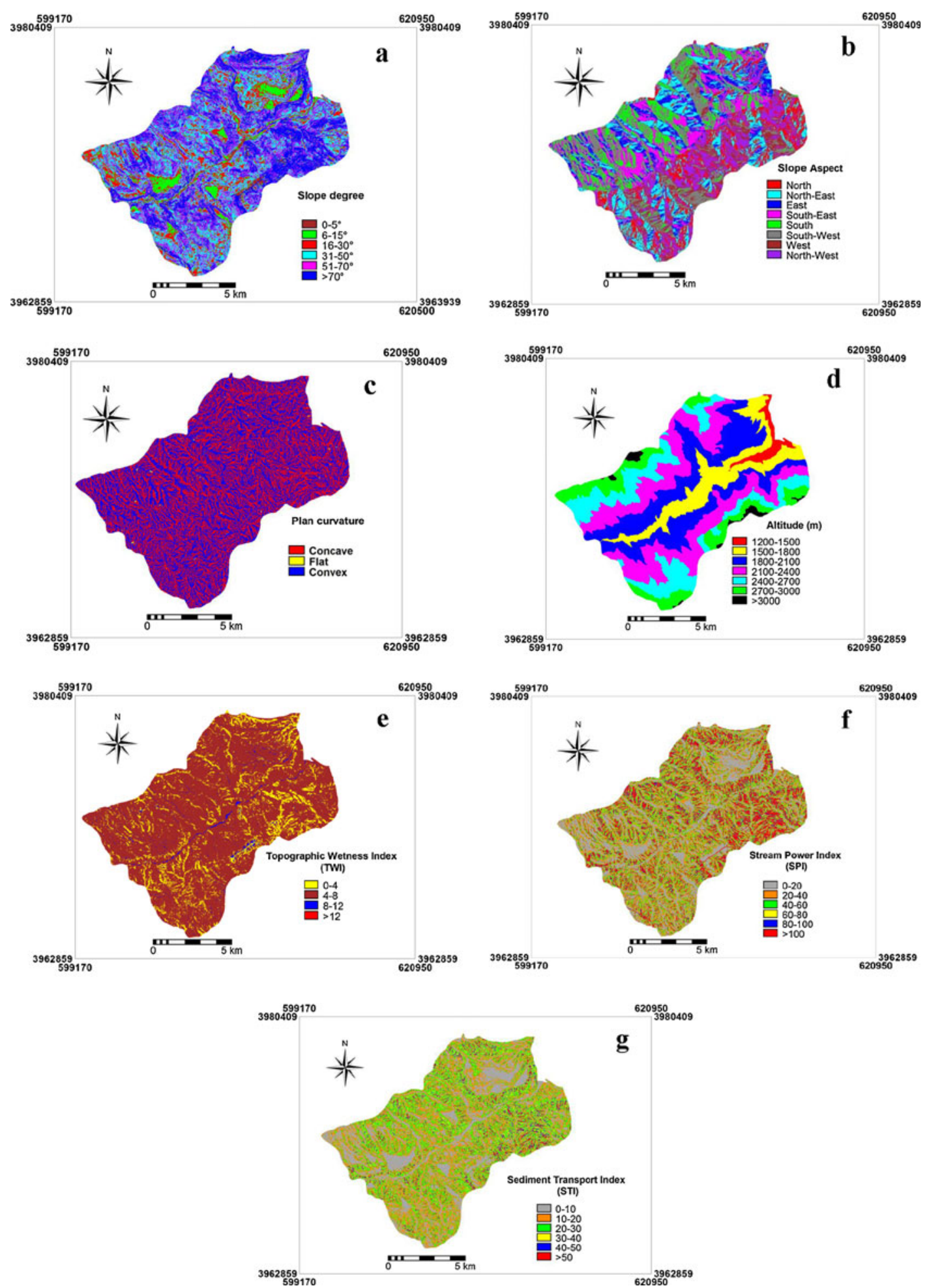

Fig. 5 Topographical parameter maps of the study area; a slope gradient, $\mathbf{b}$ slope aspect, $\mathbf{c}$ altitude, $\mathbf{d}$ plan curvature, e topographic wetness index, $\mathbf{f}$ stream power index, $\mathbf{g}$ sediment transport capacity index

study area were recognised as rotational slides according to the landslide classification system proposed by Varnes (1978). Of the 78 landslides identified randomly, $55(70 \%)$ locations were chosen for the landslide susceptibility maps, while the remaining $23(30 \%)$ cases were used for the model validation. 
Landslide conditioning factors

A geology map of the study area $(1: 100,000$ series, sheet number 6,461, prepared by Geological Survey of Iran) was digitised in the ILWIS 3.3 software environment. The study area is covered by various types of lithological formations, such as Quaternary, Eocene, Paleocene, late Cretaceous, late Jurassic, early Triassic and early Permian. The Quaternary deposits cover about $40 \%$ of the study area. The general geological setting of the area is shown in Fig. 3 and the lithological properties are summarised in Table 1.

Four different types of land use were described for this study using a supervised classification and field surveys of $E M^{+}$(2006) satellite images (Youssef et al. 2009, 2012). These types of land use were moderate pasture, best pasture, mixing orchard and agricultural and residential areas (Fig. 4). Most part of the study area (64.82\%) is covered by moderate pasture. Consequently, best pasture, mixing orchard and agriculture and residential areas are covered by $21.55 \%, 13.33 \%$, and $0.30 \%$ of the study area, respectively. A digital elevation model (DEM) was created using the topographic database. The slope gradient, slope aspect, plan curvature and three common secondary geomorphometric parameters that are relevant to the landslide analysis were calculated from the DEM. The sediment transport capacity index (LS) (Moore et al. 1988), SPI (Moore and Grayson 1991) and TWI (Moore and Grayson 1991) were derived from the DEM using the script written by Hengl et al. (2003), which was executed using the ILWIS 3.3 software (Fig. 5). The distances of the rivers, roads and faults were also digitised from the 1:50,000 and $1: 100,000$ topographic maps and the geological maps, respectively (Fig. 6).

\section{Landslide susceptibility maps and their validation}

Due to their hazardous character, many government and research institutions throughout the world have attempted to assess landslide susceptibility, hazards, and risks and to show their spatial pattern over the years. In this research, both weights-of-evidence and CF models were used for identifying the areas susceptible to landslides at the Haraz Mountains of Iran. A total of 78 landslides were mapped using aerial photographs and subsequent field survey. The landslide conditioning factors considered included slope gradient, slope aspect, altitude, lithology, land use, distance to streams, distance to roads, distance to faults, TWI, SPI,

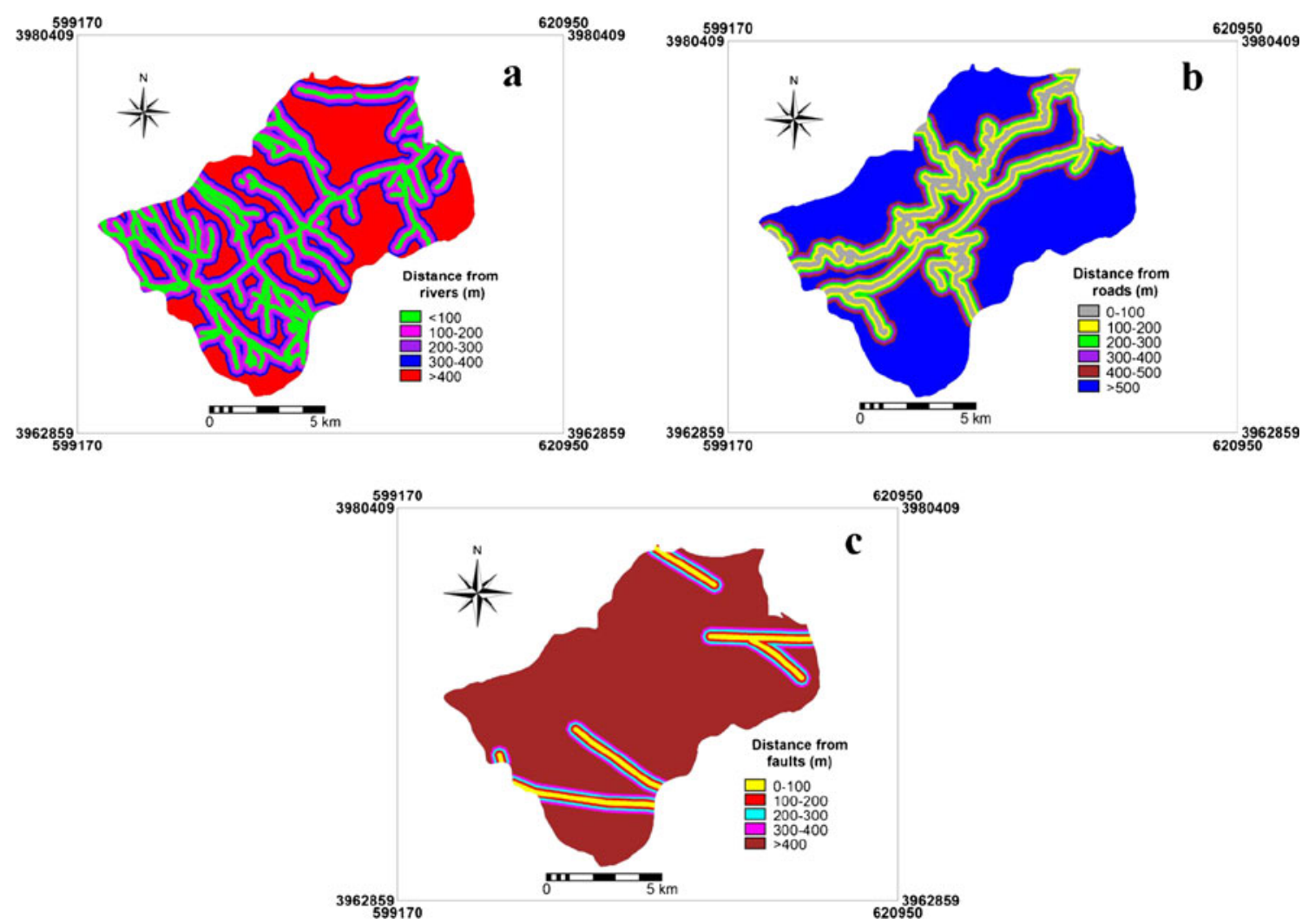

Fig. 6 a Distances from rivers, $\mathbf{b}$ distances from roads, $\mathbf{c}$ distances from faults 


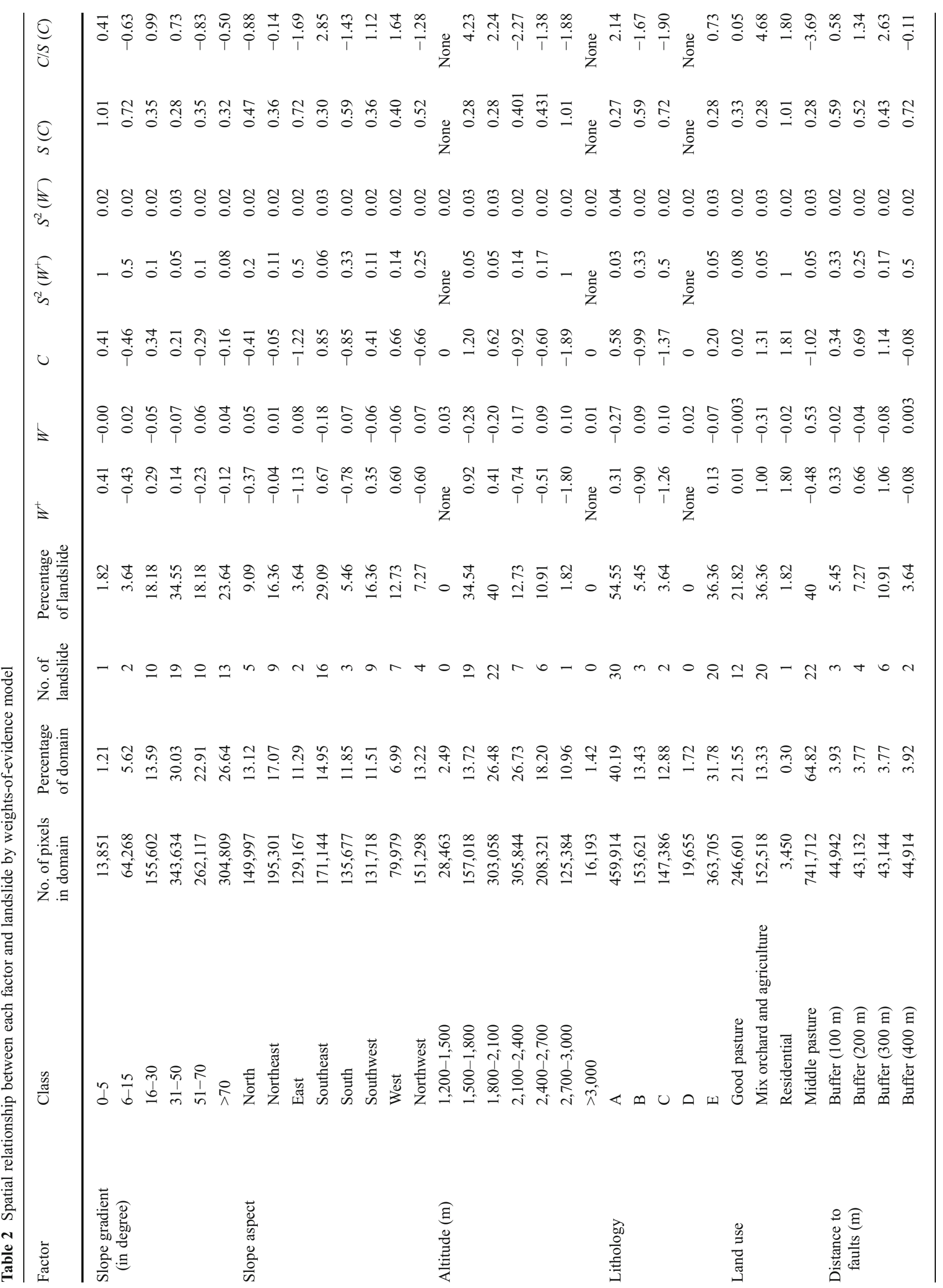




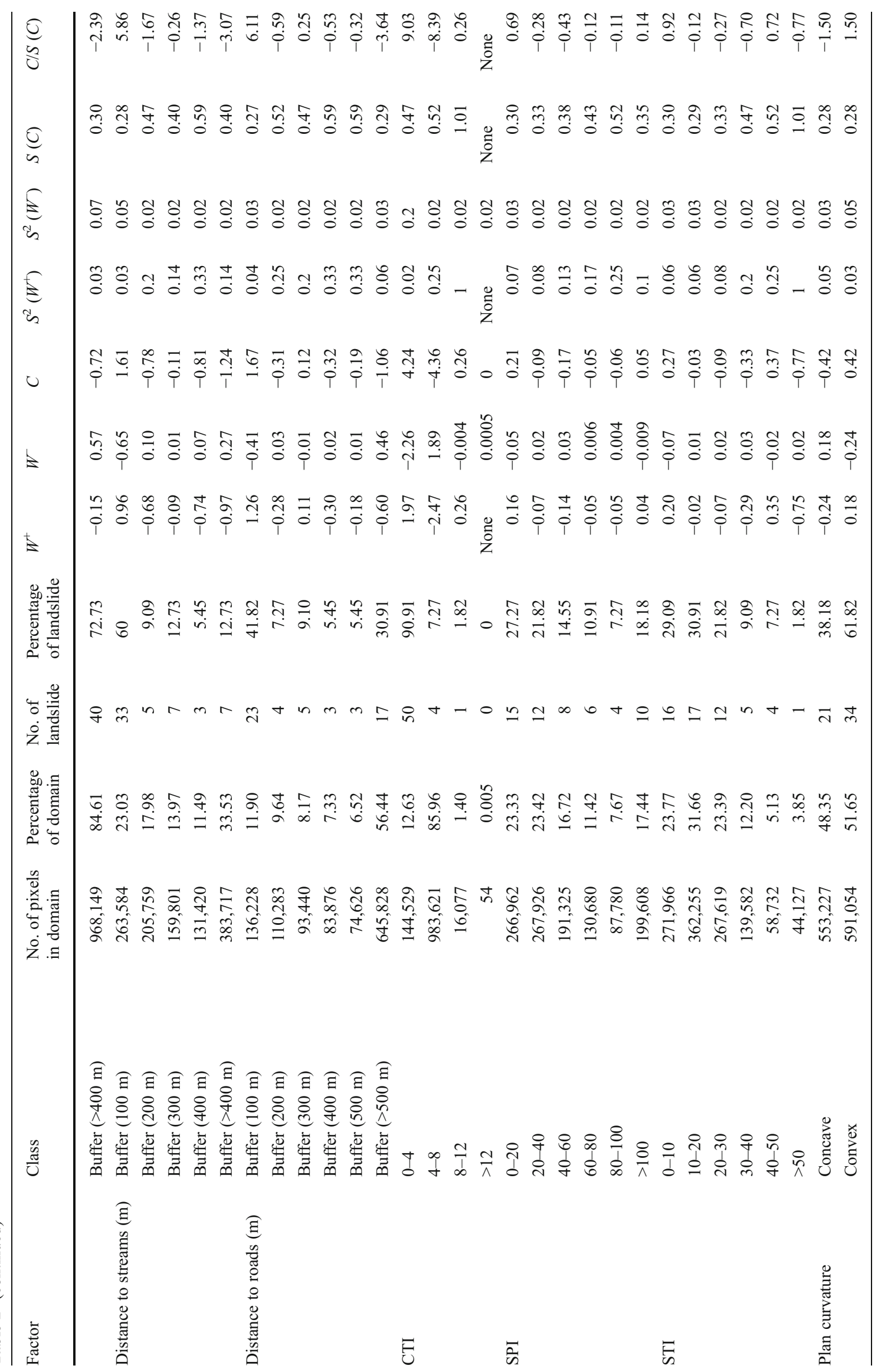


STI and plan curvature. Both weights-of-evidence and certainty factor approaches were applied to analyse the landslide susceptibility using these 12 landslide conditioning factors.

For each of the conditioning factors, the weights and contrast were calculated using the weights-of-evidence method. The magnitude of the contrast, $\mathrm{C}$, was determined from the difference, $W^{+}$and $W^{-}$that provided a measure of the spatial association between a set of points and a binary pattern (Bonham-Carter 1991). $C$ is positive for a positive spatial association and negative for a negative spatial association. The studentised value of $C$, the ratio of $C$ to standard deviation or $C / S(C)$, serves as a guide to the significance of the spatial association and acts as a measure of the relative certainty of the posterior probability (Bonham-Carter 1991). The weights and contrasts for each predictor pattern are summarized in Table 2. The contrast was set to the rating of each factor, as the contrast is related to the landslide probability. There were $1,144,281$ total pixels in the study area. The ratio $\left(W^{+}\right)$is the percentage of landslides/percentage of the domain and $C$ is the contrast. $S^{2}\left(W^{+}\right)$and $S^{2}(W)$ are the variances of $W^{+}$ and $W . S(C)$ is the standard deviation of the contrast, and $C / S$ (C) is the studentised value of the contrast (Table 2). The standard deviation of $C$ is calculated by

$S(C)=\sqrt{S^{2}\left(W^{+}\right)+S^{2}\left(W^{-}\right)}$

The relationships between the landslides and the landslide-conditioning factors, contrast and studentised $C$ are presented in Table 2 . The pixel values obtained are then classified based on natural breaks in Arc GIS 9.3 software into low, moderate, high and very high susceptibility groups to determine the class intervals in the landslide susceptibility map (Fig. 7). Similarly, landslide susceptibility index was calculated using certainty factor model. The landslide distribution for each class, expressed by the number of occurring pixels, was used to calculate $\mathrm{CF}$ values. The results of spatial relationship between landslide and conditioning factors using certainty factor model is shown in Table 3. In Table 3, slope angle classes showed that $0-5^{\circ}$ and $16-30^{\circ}$ classes have higher CF weight. As the slope angle increases, the shear stress in the soil or other unconsolidated material generally increases. Gentle slopes are expected to have a low frequency of landslides because of the generally lower shear stresses are associated with low gradients. Steep natural slopes resulting from outcropping bedrock, however, may not be susceptible to shallow landslides. In the case of slope aspect, most of the landslides occurred in south-east and west facing. This condition may be consequence of humidity in the study area. This may be due to Haraz watershed is affected by pluvial air mass from

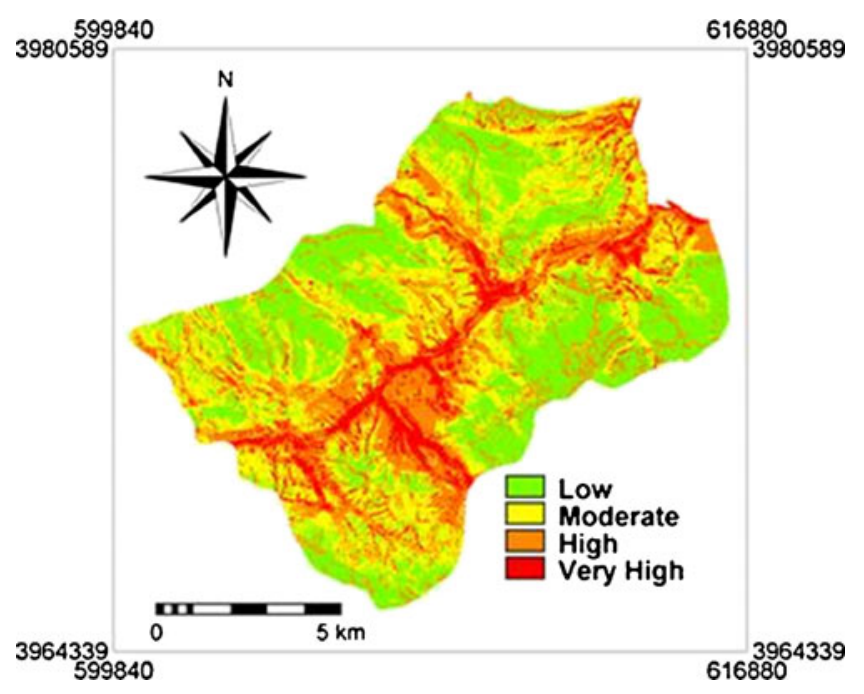

Fig. 7 Landslide susceptibility map produced by weights-of-evidence model

west and north to north-west. In the case of altitude, both 1,500-1,800 and 1,800-2,100 m classes have 34.54\% and $40 \%$ of landslide probability and CF values of 0.603 and 0.338 , respectively. Results showed that the CF values decreased with the altitude addition in the study area (Table 3). Investigation of lithological conditions showed that A group consisting of scree, young terraces and old terraces has higher value of CF (0.263). Similarly, group $\mathrm{D}\left(\mathrm{PE}_{z}\right.$ and $\left.\mathrm{PE}_{f}\right)$ has lower value of $\mathrm{CF}(-1)$. In the case of land use, higher $\mathrm{CF}$ value were for residential area (0.834) and mixing orchard and agriculture area (0.633) types of land use. This result referred to anthropogenic (human caused) interferences such as land use change. In the case distance to faults, distances between 0 and 100, 100-200 and 200-300 $\mathrm{m}$ have weight (CF) of 0.28, 0.482 and 0.654 , respectively. This means that the landslide probability is higher in these intervals. Assessment of distance from streams and roads showed that distance of $0-100 \mathrm{~m}$ has high correlation with landslide occurrence. From this observation, we can say that the general trend of the $C F$ value increases with the distance from the streams and roads. So, road construction and bank erosion are most important factors in slope imbalance causing frequent occurrence of landslides. Relation between TWI, and SPI and landslide probability showed that 0-4 and 0-20 classes have highest value of CF, respectively. Similarly, for sediment transport index, class between 40 and 50 has most CF value. The curvature values represent the morphology of the topography. A positive curvature is an upwardly convex cell, and a negative curvature is upwardly concave cell. Concave areas generally have a higher CF value than convex areas because slopes with a negative curvature retain more water and for a longer period following heavy rain than slopes with a positive curvature. The curvature area, in turn, will increase the moisture content of the soil, 
Table 3 Spatial relationship between each landslide conditioning factors and landslide by certainty factor model

\begin{tabular}{|c|c|c|c|c|c|c|}
\hline Factor & Class & $\begin{array}{l}\text { No. of pixels } \\
\text { in domain }\end{array}$ & $\begin{array}{l}\text { Percentage } \\
\text { of domain }\end{array}$ & $\begin{array}{l}\text { No. of } \\
\text { landslide }\end{array}$ & $\begin{array}{l}\text { Percentage } \\
\text { of landslide }\end{array}$ & CF Value \\
\hline \multirow[t]{6}{*}{ Slope gradient (in degree) } & $0-5$ & 13,851 & 1.21 & 1 & 1.82 & 0.334 \\
\hline & $6-15$ & 64,268 & 5.62 & 2 & 3.64 & -0.353 \\
\hline & $16-30$ & 155,602 & 13.59 & 10 & 18.18 & 0.252 \\
\hline & $31-50$ & 343,634 & 30.03 & 19 & 34.55 & 0.131 \\
\hline & $51-70$ & 262,117 & 22.91 & 10 & 18.18 & -0.206 \\
\hline & $>70$ & 304,809 & 26.64 & 13 & 23.64 & -0.113 \\
\hline \multirow[t]{8}{*}{ Slope aspect } & North & 149,997 & 13.12 & 5 & 9.09 & -0.306 \\
\hline & Northeast & 195,301 & 17.07 & 9 & 16.36 & -0.041 \\
\hline & East & 129,167 & 11.29 & 2 & 3.64 & -0.678 \\
\hline & Southeast & 171,144 & 14.95 & 16 & 29.09 & 0.486 \\
\hline & South & 135,677 & 11.85 & 3 & 5.46 & -0.54 \\
\hline & Southwest & 131,718 & 11.51 & 9 & 16.36 & 0.297 \\
\hline & West & 79,979 & 6.99 & 7 & 12.73 & 0.451 \\
\hline & Northwest & 151,298 & 13.22 & 4 & 7.27 & -0.45 \\
\hline \multirow[t]{7}{*}{ Altitude (m) } & $1,200-1,500$ & 28,463 & 2.49 & 0 & 0 & -1 \\
\hline & $1,500-1,800$ & 157,018 & 13.72 & 19 & 34.54 & 0.603 \\
\hline & $1,800-2,100$ & 303,058 & 26.48 & 22 & 40 & 0.338 \\
\hline & $2,100-2,400$ & 305,844 & 26.73 & 7 & 12.73 & -0.524 \\
\hline & $2,400-2,700$ & 208,321 & 18.20 & 6 & 10.91 & -0.401 \\
\hline & $2,700-3,000$ & 125,384 & 10.96 & 1 & 1.82 & -0.834 \\
\hline & $>3,000$ & 16,193 & 1.42 & 0 & 0 & -1 \\
\hline \multirow[t]{5}{*}{ Lithology } & A & 459,914 & 40.19 & 30 & 54.55 & 0.263 \\
\hline & $\mathrm{B}$ & 153,621 & 13.43 & 3 & 5.45 & -0.594 \\
\hline & $\mathrm{C}$ & 147,386 & 12.88 & 2 & 3.64 & -0.718 \\
\hline & $\mathrm{D}$ & 19,655 & 1.72 & 0 & 0 & -1 \\
\hline & $\mathrm{E}$ & 363,705 & 31.78 & 20 & 36.36 & 0.126 \\
\hline \multirow[t]{4}{*}{ Land use } & Best pasture & 246,601 & 21.55 & 12 & 21.82 & 0.012 \\
\hline & Mix orchard and agriculture & 152,518 & 13.33 & 20 & 36.36 & 0.633 \\
\hline & Residential & 3,450 & 0.30 & 1 & 1.82 & 0.834 \\
\hline & Moderate pasture & 741,712 & 64.82 & 22 & 40 & -0.383 \\
\hline \multirow[t]{5}{*}{ Distance to faults (m) } & Buffer $(100 \mathrm{~m})$ & 44,942 & 3.93 & 3 & 5.45 & 0.28 \\
\hline & Buffer (200 m) & 43,132 & 3.77 & 4 & 7.27 & 0.482 \\
\hline & Buffer (300 m) & 43,144 & 3.77 & 6 & 10.91 & 0.654 \\
\hline & Buffer (400 m) & 44,914 & 3.92 & 2 & 3.64 & -0.074 \\
\hline & Buffer $(>400 \mathrm{~m})$ & 968,149 & 84.61 & 40 & 72.73 & -0.14 \\
\hline \multirow[t]{5}{*}{ Distance to streams (m) } & Buffer (100 m) & 263,584 & 23.03 & 33 & 60 & 0.616 \\
\hline & Buffer (200 m) & 205,759 & 17.98 & 5 & 9.09 & -0.494 \\
\hline & Buffer (300 m) & 159,801 & 13.97 & 7 & 12.73 & -0.089 \\
\hline & Buffer (400 m) & 131,420 & 11.49 & 3 & 5.45 & -0.525 \\
\hline & Buffer $(>400 \mathrm{~m})$ & 383,717 & 33.53 & 7 & 12.73 & -0.62 \\
\hline \multirow[t]{6}{*}{ Distance to roads (m) } & Buffer (100 m) & 136,228 & 11.90 & 23 & 41.82 & 0.715 \\
\hline & Buffer (200 m) & 110,283 & 9.64 & 4 & 7.27 & -0.245 \\
\hline & Buffer (300 m) & 93,440 & 8.17 & 5 & 9.10 & 0.102 \\
\hline & Buffer (400 m) & 83,876 & 7.33 & 3 & 5.45 & -0.256 \\
\hline & Buffer (500 m) & 74,626 & 6.52 & 3 & 5.45 & -0.164 \\
\hline & Buffer $(>500 \mathrm{~m})$ & 645,828 & 56.44 & 17 & 30.91 & -0.452 \\
\hline \multirow[t]{2}{*}{ CTI } & $0-4$ & 144,529 & 12.63 & 50 & 90.91 & 0.861 \\
\hline & $4-8$ & 983,621 & 85.96 & 4 & 7.27 & -0.915 \\
\hline
\end{tabular}


Table 3 (continued)

\begin{tabular}{|c|c|c|c|c|c|c|}
\hline Factor & Class & $\begin{array}{l}\text { No. of pixels } \\
\text { in domain }\end{array}$ & $\begin{array}{l}\text { Percentage } \\
\text { of domain }\end{array}$ & $\begin{array}{l}\text { No. of } \\
\text { landslide }\end{array}$ & $\begin{array}{l}\text { Percentage } \\
\text { of landslide }\end{array}$ & CF Value \\
\hline & $8-12$ & 16,077 & 1.40 & 1 & 1.82 & 0.227 \\
\hline & $>12$ & 54 & 0.005 & 0 & 0 & -1 \\
\hline \multirow[t]{6}{*}{ SPI } & $0-20$ & 266,962 & 23.33 & 15 & 27.27 & 0.145 \\
\hline & $20-40$ & 267,926 & 23.42 & 12 & 21.82 & -0.068 \\
\hline & $40-60$ & 191,325 & 16.72 & 8 & 14.55 & -0.13 \\
\hline & $60-80$ & 130,680 & 11.42 & 6 & 10.91 & -0.045 \\
\hline & $80-100$ & 87,780 & 7.67 & 4 & 7.27 & -0.052 \\
\hline & $>100$ & 199,608 & 17.44 & 10 & 18.18 & 0.041 \\
\hline \multirow[t]{6}{*}{ STI } & $0-10$ & 271,966 & 23.77 & 16 & 29.09 & 0.183 \\
\hline & $10-20$ & 362,255 & 31.66 & 17 & 30.91 & -0.024 \\
\hline & $20-30$ & 267,619 & 23.39 & 12 & 21.82 & -0.067 \\
\hline & $30-40$ & 139,582 & 12.20 & 5 & 9.09 & -0.255 \\
\hline & $40-50$ & 58,732 & 5.13 & 4 & 7.27 & 0.294 \\
\hline & $>50$ & 44,127 & 3.85 & 1 & 1.82 & -0.529 \\
\hline \multirow[t]{2}{*}{ Plan curvature } & Concave & 553,227 & 48.35 & 21 & 38.18 & -0.21 \\
\hline & Convex & 591,054 & 51.65 & 34 & 61.82 & 0.164 \\
\hline
\end{tabular}

which will remain saturated, increase erosion and decrease soil stability (Fig. 8).

Landslide susceptibility maps without validation are of little meaningful (Chung and Fabbri 1998). In the literature, three methods of verification analyses have been presented. In the first method, a map produced by GIS is compared to another map prepared by experts using direct observations of the studied area. In the second method, the map obtained is compared with another parameter map that supports the geomorphic process mapped (Lee 2004). In the third method, the GIS-based map is matched with a part of the

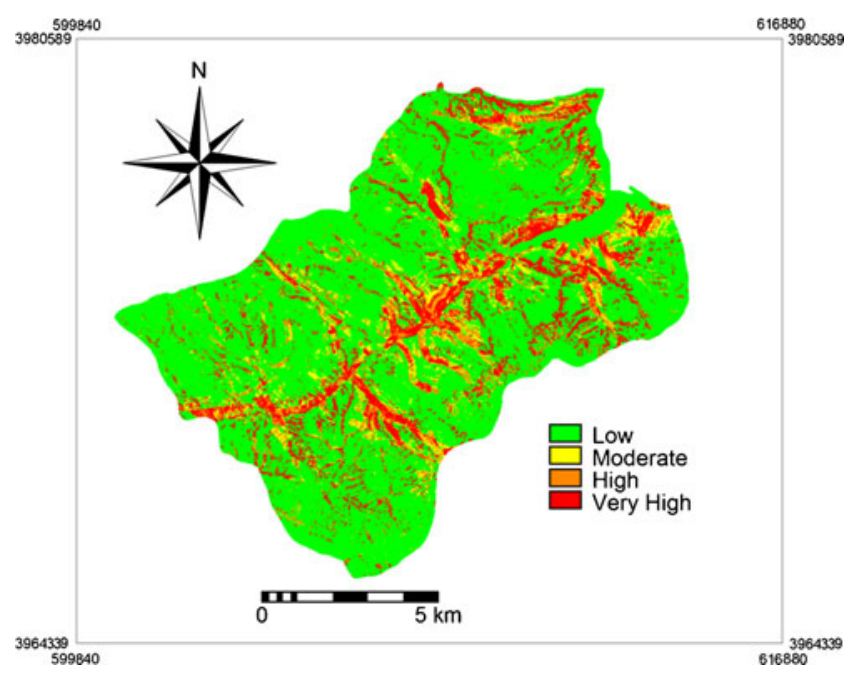

Fig. 8 Landslide susceptibility map produced by certainly factor model data set used to produce the GIS-based map. This approach to landslide susceptibility studies has been used by several authors (Remondo et al. 2003; Lee 2005; Ayalew and Yamagishi 2005; Akgun and Bulut 2007; Akgun et al. 2008; Akgun and Turk 2010). In this study, the landslide locations which were not used during the model building process were used to verify the landslide susceptibility maps.

The receiver operating characteristics (ROC) curve is a useful method for representing the quality of deterministic and probabilistic detection and forecasting systems (Swets 1988). The ROC curve is a graphical representation of the trade off between the false-negative and falsepositive rates for every possible cutoff value (Table 4). By tradition, the plot shows the false-positive rate (1 specificity) on the $x$-axis (Eq. 6) and the true-positive rate (the sensitivity or 1 -the false-negative rate) on the $y$-axis (Eq. 7).

$X=1-$ specifity $=1-\left[\frac{\mathrm{TN}}{\mathrm{TN}+\mathrm{FP}}\right]$

$Y=$ sensivity $=\left[\frac{\mathrm{TP}}{\mathrm{TP}+\mathrm{FN}}\right]$

The area under the ROC curve (area under curve (AUC)) characterises the quality of a forecast system by describing the system's ability to anticipate the correct occurrence or non-occurrence of pre-defined 'events'. The best method 
Table 4 Parameters for the calculation of ROC curve (modified from Swets (1988))

\begin{tabular}{lll}
\hline & $\begin{array}{l}\text { Landslide } \\
\text { bodies }\end{array}$ & $\begin{array}{l}\text { Landslide } \\
\text { free areas }\end{array}$ \\
\hline $\begin{array}{c}\text { Landslide occurrence based } \\
\text { on calculated function } \\
\begin{array}{c}\text { Safe areas based on } \\
\text { calculated function }\end{array}\end{array}$ & True positive (TP) & False positive (FP) \\
\hline
\end{tabular}

has a curve with the largest AUC; the AUC varies from 0.5 to 1.0. If the model does not predict the occurrence of the landslide any better than chance, the AUC would equal 0.5. An ROC curve of 1 represents perfect prediction. The quantitative-qualitative relationship between AUC and prediction accuracy can be classified as follows: 0.9-1, excellent; $0.8-0.9$, very good; $0.7-0.8$, good; $0.6-0.7$, average; and $0.5-0.6$, poor. The ROC curve for the weights-of-evidence and certainty factor models were produced based on the test data set, which was randomly collected from landslide inventory data (Yesilnacar 2005). The results of the ROC curve test are illustrated in Fig. 9. These curves indicate that, weights-ofevidence model (Fig. 9a) has relatively higher prediction performance than the certainty factor model. ROC plot assessment results showed that in the susceptibility map using weights-of-evidence model, the AUC was 0.7987 and the prediction accuracy was $79.87 \%$. In the susceptibility map using CF model, the AUC was 0.7202 and the prediction accuracy was $72.02 \%$ (Fig. 9b). According to the results of the AUC evaluation, the map produced by weights-of-evidence exhibited satisfactory result for landslide susceptibility mapping.

\section{Conclusions}

In this study, two statistical models such as weight-ofevidence and certainty factor models were used for landslide susceptibility mapping and their performances were compared. In both these models, the data acquisition and analysis were relatively easy and not very time consuming. The modelling was applied to the Haraz catchments in Iran by considering 12 landslide conditioning factors. In the topographic database, the factors were slope gradient, slope aspect, altitude, plan curvature, distance from rivers, distance from roads, TWI, SPI and STI. The lithology and distance from faults was derived from the geological database. The land-use information was extracted from Landsat $E T M^{+}$satellite imagery. An extensive landslide inventory map was produced. For this purpose, a landslide inventory database that is used to assess the landslide susceptibility of the study area, with a total of 78 landslides, was mapped in the study area. The landslide data was randomly spilt into training and testing dataset. Of the 78
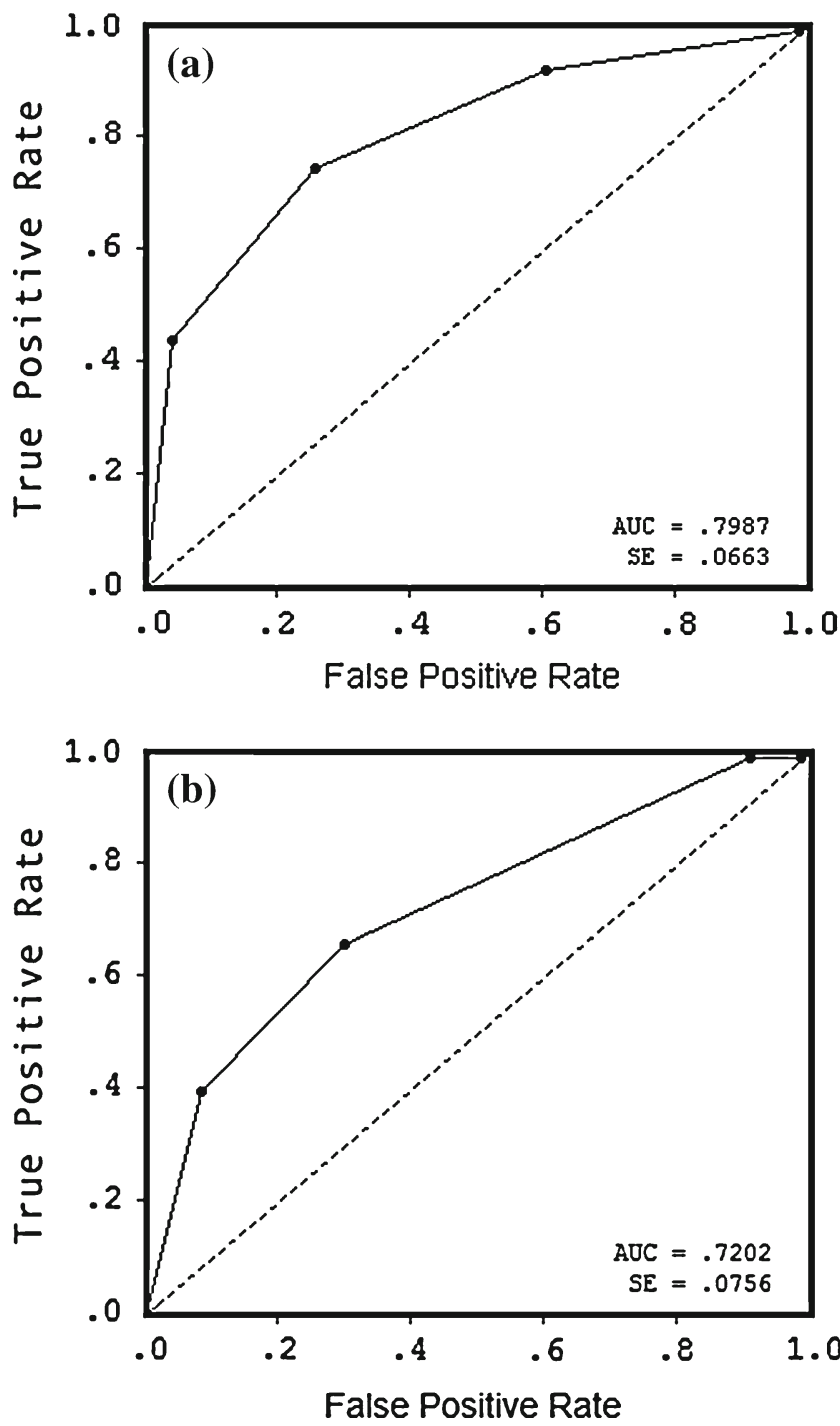

Fig. 9 ROC curve and area under the curve a for the weights-ofevidence model, $\mathbf{b}$ certainty factor model

landslides identified, randomly 55 (70\%) locations were chosen for the landslide susceptibility maps, while the remaining $23(30 \%)$ cases were used for the model validation. The ROC curve for the block entry weights-of-evidence was produced based on the test dataset, which was randomly collected from the landslide inventory map. The validation results showed that the weights-of-evidence model has slightly higher predication accuracy, i.e. $7.85 \%(79.87-72.02 \%)$, which is better than the CF model. Here, the authors can conclude that the results of the weights-of-evidence model have shown the best prediction accuracy in landslide susceptibility mapping in the study area. Prepared landslide susceptibility maps could be the basis for decisions making. The information provided by these maps could help citizens, planners and engineers to reduce losses caused by existing and future landslides by means of prevention, mitigation and avoidance. 
Acknowledgements The authors are thankful to anonymous reviewers for their valuable comments which were very useful in bringing the manuscript into its present form. Prof. Pradhan would like to thank the Alexander von Humboldt (AvH) Foundation, Germany, for providing fellowship which is thankfully acknowledged.

\section{References}

Akgun A, Bulut F (2007) GIS-based landslide susceptibility for Arsin-Yomra (Trabzon, North Turkey) region. Environ Geol 51:1377-1387

Akgun A, Turk N (2010) Landslide susceptibility mapping for Ayvalik (Western Turkey) and its vicinity by multi criteria decision analysis. Environ Earth Sci 61:595-611

Akgun A, Dag S, Bulut F (2008) Landslide susceptibility mapping for a landslide-prone area (Findikli, NE of Turkey) by likelihood frequency ratio and weighted linear combination models. Environ Geol 54(6):1127-1143

Akgun A, Kincal C, Pradhan B (2011) Application of remote sensing data and GIS for landslide risk assessment as an environmental threat to Izmir city (West Turkey). Environ Monit Assess. doi:10.1007/s10661-011-2352-8, Article on-line first available

Akgun A, Sezer EA, Nefeslioglu HA, Gokceoglu C, Pradhan B (2012) An easy-to-use MATLAB program (MamLand) for the assessment of landslide susceptibility using a Mamdani fuzzy algorithm. Comput Geosci 38(1):23-34

Aleotti P, Chowdhury R (1999) Landslide hazard assessment: summary review and new perspectives. Bull Eng Geol Environ 58:21-44

Ayalew L, Yamagishi H (2005) The application of GIS-based logistic regression for landslide susceptibility mapping in the KakudaYahiko Mountains, Central Japan. Geomorphology 65:15-31

Ayalew L, Yamagishi H, Ugawa N (2004) Landslide susceptibility mapping using GIS based weighted linear combination, the case in Tsugawa area of Agano River, Niigata Prefecture, Japan. Landslides 1(1):73-81

Binaghi E, Luzi L, Madella P, Pergalani F, Rampini A (1998) Slope instability zonation: a comparison between certainty factor and Fuzzy Dempster-Shafer approaches. Nat Hazards 17:77-97

Biswajeet P, Saied P (2010) Comparison between prediction capabilities of neural network and fuzzy logic techniques for landslide susceptibility mapping. Disaster Advances 3 (2):26-34

Bonham-Carter GF (1991) Integration of geoscientific data using GIS. In: Goodchild MF, Rhind DW, Maguire DJ (eds) Geographic information systems: principle and applications. Longdom, London, pp 171-184

Bui HB, Nguyen Q, Nguyen VT (2008) GIS-based weight of evidence modeling for landslide susceptibility mapping at Jaechon area, Korea, International Symposium on Geoinformatics for Spatial Infrastructure Development in Earth and Allied Sciences pp 4

Bui DT, Pradhan B, Lofman O, Revhaug I, Dick OB (2011) Landslide susceptibility mapping at Hoa Binh province (Vietnam) using an adaptive neuro fuzzy inference system and GIS. Comput Geosci. doi:10.1016/j.cageo.2011.10.031, article on-line first available

Çevik E, Topal T (2003) GIS-based landslide susceptibility mapping for a problematic segment of the natural gas pipeline, Hendek (Turkey). Environ Geol 44:949-962

Chung CF, Fabbri AG (1993) The representation of geoscience information for data integration. Non-renew Resour 2(2):122-139

Chung CJF, Fabbri AG (1998) Three Bayesian prediction models for landslide hazard. In: Buccianti A, Nardi G, Potenza R (eds.)
Proceedings of International Association for Mathematical Geology 1998 Annual Meeting (IAMG'98), Ischia, Italy, October 1998. pp. 204-211

Chung CJ, Fabbri AG (2003) Validation of spatial prediction models for landslide hazard mapping. Nat Hazards 30:451-472

Chung CJ, Fabbri A (2005) Systematic procedures of landslide hazard mapping for risk assessment using spatial prediction models. In: Glade T, Anderson MG, Crozier MJ (eds) Landslide hazard and risk. Wiley, New York, pp 139-177

Gokceoglu C, Sonmez H, Nefeslioglu HA, Duman TY, Can T (2005) The March 17, 2005 Kuzulu landslide (Sivas, Turkey) and landslide susceptibility map of its near vicinity. Eng Geol 81(1):65-83

Gorsevski PV, Gessler PE, Jankowski P (2003) Integrating a fuzzy $k$-means classification and a Bayesian approach for spatial prediction of landslide hazard. J Geogr Syst 5(3):223-251

Gupta RP, Joshi BC (1990) Landslide hazard zoning using the GIS approach - a case study from the Ramganga catchment, Himalayas. Eng Geol 28:119-131

Guzzetti F (2005) Landslide hazard and risk assessment, PhD thesis, University Bonn, pp 389

Guzzetti F, Carrara A, Cardinalli M, Reichenbach P (1999) Landslide hazard evaluation: a review of current techniques and their application in a multi-case study, central Italy. Geomorphology 31:181-216

Hengl T, Gruber S, Shrestha DP (2003) Digital terrain analysis in ILWIS. International Institute for Geo-Information Science and Earth Observation Enschede, The Netherlands, pp 62

Kanungo DP, Sarkar S, Sharma S (2011) Combining neural network with fuzzy, certainty factor and likelihood ratio concepts for spatial prediction of landslides. Nat Hazards 59:1491-1512

Lan HX, Zhou CH, Wang LJ, Zhang HY, Li RH (2004) Landslide hazard spatial analysis and prediction using GIS in the Xiaojiang watershed, Yunnan, China. Eng Geol 76:109-128

Lee S (2004) Soil erosion assessment and its verification using the universal soil loss equation and geographic information system: a case study at Boun, Korea. Environ Geol 45(4):457-465

Lee S (2005) Application of logistic regression model and its validation for landslide susceptibility mapping using GIS and remote sensing data. Int J Remote Sens 26:1477-1491

Lee S, Pradhan B (2006) Probabilistic landslide hazards and risk mapping on Penang Island, Malaysia. J Earth Syst Sci 115 (6):661-667

Lee S, Pradhan B (2007) Landslide hazard mapping at Selangor, Malaysia using frequency ratio and logistic regression models. Landslides 4(1):33-41

Lee S, Choi J, Min K (2002a) Landslide susceptibility analysis and verification using the Bayesian probability model. Environ Geol 43(1-2):120-131

Lee S, Chwae U, Min K (2002b) Landslide susceptibility mapping by correlation between topography and geological structure: the Janghung area, Korea. Geomorphology 46(3-4):149-162

Lin ML, Tung CC (2004) A GIS-based potential analysis of the landslides induced by the Chi-Chi earthquake. Eng Geol 71(1-2):63-77

Luzi L, Pergalani F (1999) Slope instability in static and dynamic conditions for urban planning: the 'Oltre Po Pavese' case history (Regione Lombardia-Italy). Nat Hazards 20:57-82

Mathew J, Jha VK, Rawat GS (2007) Weights of evidence modeling for landslide hazard zonation mapping in part of Bhagirathi valley, Uttarakhand. Curr Sci 92(5):628-638

Moore ID, Grayson RB (1991) Terrain-based catchment partitioning and runoff prediction using vector elevation data. Water Resour Res 27(6):1171-1191

Moore ID, O'Loughlin EM, Burch GJ (1988) A computer based topographic model and its hydrologic and ecological applications. Earth Surf Proc Land 13:305-320 
Neuhäuser B, Terhorst B (2007) Landslide susceptibility assessment using "weights-of-evidence" applied to a study area at the Jurassic escarpment (SW- Germany). Geomorphology 86:12-24

Oh HJ, Lee S (2011) Cross-application used to validate landslide susceptibility maps using a probabilistic model from Korea. Environ Earth Sci 64(2):395-409

Oh HJ, Pradhan B (2011) Application of a neuro-fuzzy model to landslide-susceptibility mapping for shallow landslides in a tropical hilly area. Comput Geosci 37(9):1264-1276. doi:10.1016/j.cageo.2010.10.012

Pourghasemi HR (2008) Landslide Hazard Assessment using Fuzzy Logic (Case Study: A part of Haraz Watershed). A thesis presented for M.Sc. degree in Watershed Management, Faculty of Natural Resources, Department of Watershed Management, Tarbiat Modarres University, Iran, $92 \mathrm{pp}$

Pradhan B (2010a) Application of an advanced fuzzy logic model for landslide susceptibility analysis. Int J Comput Int Sys 3(3):370-381

Pradhan B (2010b) Landslide susceptibility mapping of a catchment area using frequency ratio, fuzzy logic and multivariate logistic regression approaches. J Indian Soc Remote Sens 38(2):301-320. doi:10.1007/s12524-010-0020-z

Pradhan B (2010c) Remote sensing and GIS-based landslide hazard analysis and cross-validation using multivariate logistic regression model on three test areas in Malaysia. Adv Space Res 45 (10):1244-1256. doi:10.1016/j.asr.2010.01.006

Pradhan B (2011a) Manifestation of an advanced fuzzy logic model coupled with geoinformation techniques for landslide susceptibility analysis. Environ Ecol Stat 18(3):471-493. doi:10.1007/ s10651-010-0147-7

Pradhan B (2011b) Use of GIS-based fuzzy logic relations and its cross application to produce landslide susceptibility maps in three test areas in Malaysia. Environ Earth Sci 63(2):329-349

Pradhan B, Buchroithner MF (2010) Comparison and validation of landslide susceptibility maps using an artificial neural network model for three test areas in Malaysia. Environ Eng Geosci 16 (2):107-126. doi:10.2113/gseegeosci.16.2.107

Pradhan B, Lee S (2010a) Delineation of landslide hazard areas on Penang Island, Malaysia, by using frequency ratio, logistic regression, and artificial neural network models. Environ Earth Sci 60 (5): 1037-1054

Pradhan B, Lee S (2010b) Landslide susceptibility assessment and factor effect analysis: back-propagation artificial neural networks and their comparison with frequency ratio and bivariate logistic regression modelling. Environ Model Softw 25(6):747-759

Pradhan B, Youssef AM (2010) Manifestation of remote sensing data and GIS on landslide hazard analysis using spatial-based statistical models. Arab J Geosci 3(3):319-326

Pradhan B, Lee S, Buchroithner MF (2009) Use of geospatial data for the development of fuzzy algebraic operators to landslide hazard mapping: a case study in Malaysia. Appl Geomatics 1:3-15

Pradhan B, Lee S, Buchroithner MF (2010a) A GIS-based backpropagation neural network model and its cross-application and validation for landslide susceptibility analyses. Comput Environ Urban 34(3):216-235

Pradhan B, Lee S, Buchroithner MF (2010b) Remote sensing and GISbased landslide susceptibility analysis and its cross-validation in three test areas using a frequency ratio model. Photogramm Fernerkun 2010(1):17-32. doi:10.1127/14328364/2010/0037

Pradhan B, Oh HJ, Buchroithner M (2010c) Weights-of-evidence model applied to landslide susceptibility mapping in a tropical hilly area. Geomatics Nat Hazards Risk 1(3):199-223. doi:10.1080/19475705.2010.498151
Pradhan B, Youssef AM, Varathrajoo R (2010d) Approaches for delineating landslide hazard areas using different training sites in an advanced artificial neural network model. Geo-Spat Inf Sci 13 (2):93-102. doi:10.1007/s11806-010-0236-7

Pradhan B, Sezer EA, Gokceoglu C, Buchroithner MF (2010e) Landslide susceptibility mapping by neuro-fuzzy approach in a landslide-prone area (Cameron Highlands, Malaysia). IEEE T Geosci Remote 48(12):4164-4177

Pradhan B, Mansor S, Pirasteh S, Buchroithner M (2011) Landslide hazard and risk analyses at a landslide prone catchment area using statistical based geospatial model. Int J Remote Sens 32 (14):4075-4087. doi:10.1080/01431161.2010.484433

Pradhan B, Chaudhari A, Adinarayana J, Buchroithner MF (2012) Soil erosion assessment and its correlation with landslide events using remote sensing data and GIS: a case study at Penang Island, Malaysia. Environ Monit Assess 184(2):715-727. doi:10.1007/ s10661-011-1996-8

Regmi NR, Giardino JR, Vitek JD (2010) Modeling susceptibility to landslides using the weight of evidence approach: Western Colorado, USA. Geomorphology 115:172-187

Remondo J, Gonzalez A, Diaz De Teran JR, Cendrero A, Fabbri A, Cheng CF (2003) Validation of landslide susceptibility maps: examples and applications from a case study in Northern Spain. Nat Hazards 30(3):437-449

Saha AK, Gupta RP, Sarkar I, Arora KM, Csaplovics E (2005) An approach for GIS-based statistical landslide susceptibility zonation - with a case study in the Himalayas. Landslides 2 (1):61-69

Schuster R (1996) Socioeconomic significances of landslides. In: Turner AK, Shuster RL (eds) Landslides Investigation and Mitigation, Transportation Research Board, Natural Research Council. National Academic Press, Washington, pp 12-36

Sezer EA, Pradhan B, Gokceoglu C (2011) Manifestation of an adaptive neuro-fuzzy model on landslide susceptibility mapping: Klang valley, Malaysia. Expert Syst Appl 38(7):82088219

Swets JA (1988) Measuring the accuracy of diagnostic systems. Science 240:1285-1293

Varnes DJ (1978) Slope movement types and processes. In: Schuster RL, Krizek RJ (eds) Landslides analysis and control. Special report, vol 176. Trasportation Research Board, National Academy of Sciences, New York, pp 12-33

Wu S, Jin Y, Zhang Y, Shi J, Dong C, Lei W, Shi L, Tan C, Hu D (2004) Investigations and assessment of the landslide hazards of Fengdu County in the reservoir region of the Three Gorges project on the Yangtze River. Environ Geol 45(4):560-566

Yesilnacar EK (2005) The application of computational intelligence to landslide susceptibility mapping in Turkey, Ph.D Thesis. Department of Geomatics the University of Melbourne, pp 423

Youssef AM, Pradhan B, Gaber AFD, Buchroithner MF (2009) Geomorphological hazard analysis along the Egyptian Red Sea coast between Safaga and Quseir. Nat Hazards Earth Syst Sci 9:751-766

Youssef AM, Pradhan B, Sabtan AA, El-Harbi HM (2012) Coupling of remote sensing data aided with field investigations for geological hazards assessment in Jazan area, Kingdom of Saudi Arabia. Environ Earth Sci 65(1):119-130. doi:10.1007/s12665-0111071-3

Zhu C, Wang X (2009) Landslide susceptibility mapping: a comparison of information and weights-of evidence methods in Three Gorges Area, 2009 International Conference on Environmental Science and Information Application Technology 342-346. doi:10.1109/ESIAT.2009.187 